Article

\title{
Institutional Innovation for Nature-Based Coastal Adaptation: Lessons from Salt Marsh Restoration in Nova Scotia, Canada
}

\author{
H. M. Tuihedur Rahman ${ }^{1,2, * \mathbb{D}}$, Kate Sherren ${ }^{1}(\mathbb{D})$ and Danika van Proosdij ${ }^{2}$ \\ 1 School for Resource and Environmental Studies, Dalhousie University, Halifax, NS B3H 4R2, Canada; \\ kate.sherren@dal.ca \\ 2 Department of Geography and Environmental Studies, Saint Mary's University, Halifax, NS B3H 3C3, \\ Canada; dvanproo@smu.ca \\ * Correspondence: hm.rahman@mail.mcgill.ca
}

Received: 23 October 2019; Accepted: 23 November 2019; Published: 27 November 2019

\begin{abstract}
Sea-levels have been rising at a faster rate than expected. Because of the maladaptive outcomes of engineering-based hard coastal protection infrastructure, policy makers are looking for alternative adaptation approaches to buffer against coastal flooding-commonly known as nature-based coastal adaptation ( $\mathrm{NbCA}$ ). However, how to implement $\mathrm{NbCA}$ under an institutional structure demonstrating 'inertia' to alternative adaptation approaches is a question that seeks scientific attention. Building on a case study derived from a highly climate-vulnerable Canadian province, this study shows how the entrepreneurial use of scientific information and institutional opportunities helped institutional actors overcome the inertia. Drawing on secondary document analysis and primary qualitative data, this study offers five key lessons to institutional actors aiming at implementing NbCA: (i) develop knowledge networks to help avoid uncertainty; (ii) identify and utilize opportunities within existing institutions; (iii) distribute roles and responsibilities among actors based on their capacity to mobilize required resources; (iv) provide entrepreneurial actors with decision-making autonomy for developing agreed-upon rules and norms; and (v) facilitate repeated interactions among institutional actors to develop a collaborative network among them. This study, therefore, helps us to understand how to implement a relatively new adaptation option by building trust-based networks among diverse and relevant institutional actors.
\end{abstract}

Keywords: institutional entrepreneurship; polycentricity; bureaucratic autonomy; institutional inertia; sea-level rise

\section{Introduction}

According to the Fifth Assessment Report (AR5) of the Intergovernmental Panel on Climate Change (IPCC), global sea-levels will be rising throughout the first half of this century at a rate of $3.7 \mathrm{~mm} \mathrm{yr}^{-1}$, driving our coastal resources and ecosystems to an unprecedented future [1]. Coastal population density and investment for more such development are growing despite an increasing demand for protection from sea-level rise (SLR) across the world [1-4]. Hinkel et al. estimated that the global cost of maintaining and rebuilding hard protection infrastructures like dykes-a common coastal protection approach practiced across the world-will reach US\$12-72 billion by 2100 [5], although questions remain regarding the extent to which such barriers are sustainable to protect our vulnerable coasts. Dugan et al. [6] noted that hard coastal protection (e.g., groynes, breakwaters) intensifies coastal development and population growth $[4,7,8]$, exacerbating future costs for protection $[9,10]$. From an ecological standpoint, hard infrastructures alter the morphologic and hydrodynamic properties of coastal ecosystems $[10,11]$ by modifying wave regimes, sediment 
dynamics and deposition processes [6,12], and squeezing out the ecosystems that can bring coastal resilience to flood and erosion problems [11,13-15]. Moreover, Sovacool [11,16] noted that coastal hardening reduces opportunities to sequester greenhouse gases. In addition, once established, the hard infrastructures are difficult to modify, which eventually reduces adaptability with changing social, economic and environmental demands [9]. Considering the limitations, Jones et al. [17] concluded that hard-coastal protection infrastructures may be 'maladaptive' (for details, see Barnett and O'Neill [9] and Juhola et al. [18]). Therefore, Temmerman et al. [14] suggested that hard protection should be limited to the areas that already have lost natural capacities to buffer SLR problems due to development (e.g., New York, New Orleans, Shanghai, Tokyo etc.). Such urbanized coasts are where the Organization of Economic Cooperation and Development (OECD) recently reported that hard protection is cost-effective [19]; elsewhere, alterative protection approaches should be sought enhancing the natural coastal and ecosystem processes that have the capacity to buffer SLR impacts.

Several adaptation approaches have been developed to enhance and utilize ecosystems to build coastal resilience to SLR impacts like floods and erosion, including ecological engineering [20], natural infrastructure [21,22], and ecosystem-based adaptation [23]. Each approach has technical implementation processes to inform their suitability to context-specific adaptation requirements. However, the outcomes of these approaches have many similarities (e.g., creating natural habitats, conserving natural ecosystems, developing natural carbon sinks). Building on these similarities, we encapsulate these approaches under a common term-nature-based coastal adaptation ( $\mathrm{NbCA}$ ). We define $\mathrm{NbCA}$ as any coastal adaptation approach that uses (i) ecologically available adaptation options (e.g., natural space, ecological process and species) and (ii) socio-politically available opportunities (e.g., values, policy, rules and regulations) (iii) to allow for natural adjustment to coastal climate change impacts, (iv) considering societal demand for diverse ecosystem services (e.g., provisioning, regulating, cultural and supporting) (v) minimizing engineered construction as a supporting component. Common examples of $\mathrm{NbCA}$ include managed realignment of existing coastal defense lines to create natural foreshore tidal marsh habitat, greening shorelines through planting, restoring saltmarshes, relocating houses and infrastructures. Several ecosystem services are associated with $\mathrm{NbCA}$. For example, mangrove ecosystems, saltmarshes and reef systems reduce $31 \%, 72 \%$ and $70 \%$ of wave height, respectively $[12,13,24,25]$. Moreover, these natural systems are self-repairing, so they provide wave attenuation services with low or no cost $[10,13,26]$. However, implementing NbCA requires context-specific knowledge, technological innovation, policy provisions, community participation, land, and financial resources. It can be difficult to accumulate all these resources under policy and institutional structures that are designed for hard protection measures. Thus, the adoption and implementation of $\mathrm{NbCA}$ as a coastal adaptation measure may call for institutional change.

According to North [27], "institutions are the humanly devised constraints that structure political, economic and social interaction" (p.97). Building on this definition, institutional economists summarized that institutions are devices for economizing transaction costs among institutional actors through rational exchange $[28,29]$. Rational actions are subjectively perceived as such by any individual-also known as political actors-who participates in political decision making and implementation [28]. When agreed-upon, political decisions are made through bargaining among the actors, institutions are constituted as rules, acts, policies, norms, values and customs to guide human actions $[28,30,31]$. In so doing, institutions distribute hierarchical authority to specific actors for implementing political decisions-also known as bureaucratic polity [32]. Political sociologists view institutions as a medium of conferring legitimacy to human actions and authority [29,33]. By setting the standards of actions, institutions justify what action is 'right' and what is 'wrong' $[28,33]$. Therefore, institutions provide a cognitive process for making sense of individuals' actions [29]. Successful institutions are often believed to be 'long-enduring' [28,34], indicating that institutions are the 'stable design for chronically repeated activity sequences' protected by agreed-upon sanctioning mechanisms [29].

Stable institutional designs that delineate and maintain the roles and responsibilities of institutional actors to suit a stable environmental state may cause 'inertia' by constraining new 
opportunities [35]. The implementation of adaptation approaches like NbCA is challenged by the institutional inertia for implementing more conventional adaptation approaches like hard coastal protection. The implementation of $\mathrm{NbCA}$ may require some de-institutionalization to redistribute the roles and responsibilities of institutional actors in the form of a new institutional arrangement [36] - a process also known as 'institutional innovation' [37,38]. Drawing on a coastal salt mash restoration project for adapting to the flooding problems of the Town of Truro, Nova Scotia, Canada, this paper expands the institutional innovation concept in the $\mathrm{NbCA}$ literature to exemplify how a new institutional arrangement can emerge through communication, trust building, diplomatic networking, making sense of messy social situations, political advocacy and leadership among institutional actors [37].

Building on the institutional entrepreneurship [39] literature, the next section expands the concept of institutional innovation in $\mathrm{NbCA}$, which is followed by a background of the case study. Next, we elucidate our data collection and analytical process and describe the results of the study based on the theoretical framework. Before summarizing and concluding the paper, we specify the key messages of this study by discussing our results through the lens of our theoretical framework.

\section{Institutional Innovation for $\mathrm{NbCA}$}

New adaptation approaches like NbCA do not function in an institutional vacuum [40]. Rather, $\mathrm{NbCA}$ calls for institutional innovation and change to incorporate advanced knowledge on environmental problems like SLR and novel solutions into decision, implementation and monitoring actions [41]. Institutions in conventional bureaucratic systems have hierarchically distributed power and authority structures [42,43] that can constrain the flow of new knowledge and thus limit the capacity of institutional actors to develop appropriate adaptation strategies [44]. For example, while local government officials in Bangladesh observe that hard flood protection infrastructures are counter-productive to long-term climate adaptation and wildlife habitat conservation, they cannot influence the government's decision of building embankments in the wetlands of the country's north-eastern floodplain because of their limited power and access to decision-making processes [45].

In addition to building common understanding about climate change impacts among institutional actors, institutions may need to be rearranged to allow for the redistribution of power and authority among stakeholders to facilitate policies and thus practical implementation of NbCA [38]. However, institutions are the systems of common understanding among actors that are maintained and monitored under the guidance of legally constituted policy documents [46]. Ostrom [30] suggested that such documents are difficult to change and because they function as foundations to future policy making [47], and cause 'institutional inertia' [40]—a key constraint to institutional change [35,48]. Institutional inertia is viewed, in the climate change literature, as the inability of institutional actors to adapt rules for evaluating new climate change conditions (e.g., unprecedented SLR impacts) based on new knowledge and information and the inability of institutions to develop timely responses to climate change impacts [49,50]. Munck af Rosenschöld et al. [49] identified five factors that contribute to institutional inertia: (i) cost-incurred for building collective action, communication and negotiation among actors for bringing change to institutional status quo [50]; (ii) uncertainty-around the framing and potential impacts of SLR contributing to the postponement of policy actions as a rational choice [7]; (iii) path-dependency-trapping institutions into the legacy of adaptation policies and technological lock-ins like hard infrastructure-based adaptation [51]; (iv) power-distributed in a fuzzy way among actors who have diverse interests and priorities based on respective roles and mandates [52]; and (v) legitimacy—influenced by cognitive bias to extant adaptation actions (e.g., hard infrastructures), constraining the adoption of new adaptation approaches [47]. Thus, it is still unclear how institutional actors (e.g., bureaucrats) embedded in a hierarchically structured system envision innovative institutional change and influence others to adopt it $[29,53]$.

Institutions are polycentric [54]. A polycentric institutional system is "composed of (1) many autonomous units formally independent of one another, (2) choosing to act in ways that take account of others, (3) through processes of cooperation, competition, conflict, and conflict resolutions" [42] 
(p. 45). In a polycentric institutional system, decision-making actors are free to pursue their interests without violating the general rule of taking account of others' interests [42]. For example, coastal systems are multijurisdictional places, where multiple government agencies perform their designated roles and functions for pursuing respective interests like regulating fisheries, maintaining offshore transportation and infrastructure, and protecting inlands from coastal floods and storms [55]. Each agency, designated responsibility for pursuing their roles, is free to choose actions under the guidance of their respective institutional rules and policies. Therefore, polycentricity can be viewed as a process of conferring 'bureaucratic autonomy' by a government's political system [56]. Fukuyama [56] suggested that political systems often endow overlapping and sometimes downright contradictory authority, consistent with Ostrom [42], who stated that uncoordinated actions among agencies can produce overlapping and duplication of services. Therefore, the institutional innovations that will facilitate the adoption and implementation of new adaptation practices are those that will initiate and build coordination among the agencies, perhaps with redistribution of roles, responsibilities and authorities among the autonomous bureaucrats and their agencies. Coordination among agencies without violating the general rule structure of bureaucracy needs collective agreement among the implicated institutional actors, and this calls for visionary and entrepreneurial leadership [57]. Thus, Garud et al. [29] suggested that in addition to contributing to institutional inertia, hierarchical institutional structures also provide the platforms for institutional change through entrepreneurial innovation.

\subsection{Institutional Entrepreneurship}

According to Maguire et al. [58], "institutional entrepreneurship represents the activities of actors who have an interest in particular institutional arrangements and who leverage resources to create new institutions or to transform existing ones". Institutional entrepreneurs shape emerging institutions and transform existing ones by proposing innovative ideas despite the challenges of institutional path-dependency and institutional inertia [29]. To initiate change in institutions, entrepreneurs seek opportunities relevant to the interests of multiple institutional actors and create shared meaning for integrating the functioning of the implicated institutions $[29,59]$. In that sense, institutional entrepreneurs are the actors who challenge the structural rigidity of institutions and offer alternative alignments of roles to better respond to the changing demand of adaptation [60]. Opportunities are the institutionally given permits for actors to propose new institutional structures and pursue actions to bring about change [61]. Phillips and Tracey [62] suggested that opportunities may remain hidden if institutional actors are not creative or simply ignorant about their institutional constraints and autonomy. Thus, to become an institutional entrepreneur, actors need either to recognize or create opportunities to re-align competing interests towards collective action and devise robust new sequences of interactions with other institutional actors [59]. Therefore, to mobilize opportunities and ideas into action, entrepreneurs need to possess the institutional authority to earn confidence and build acceptance among diverse institutional actors, attract other actors by crafting appealing arguments in support of entrepreneurial interests, and build connections between existing institutional practices and proposed institutional changes by being flexible and reflexive to the competing interests of diverse institutional actors [58,62].

\subsection{Operationalizing Institutional Entrepreneurship for Institutional Innovation}

Building on Maguire et al. [58], Garud et al. [29] and Emirbayer and Mische [63], we identified five tasks for an institutional entrepreneur to initiate institutional change in support of implementing new adaptation approaches like $\mathrm{NbCA}$ (Figure 1). First, by comprehending and framing a problem, an institutional actor initiates an entrepreneurial endeavor. Problem framing entails clear and concise communication of knowledge about climate change impacts being inadequately addressed within an institutional jurisdiction [36]. Mintrom and Luetjens [64] suggested that by presenting the scientific evidence of climate change impacts (e.g., SLR), entrepreneurs highlight a crisis at hand, which requires access to knowledge networks and the capacity of entrepreneurs to interpret that knowledge [65]. 
Mondou et al. [66] emphasized that access to knowledge networks is necessary but not enough; long-term and active participation in knowledge networks is key to evidence-based problem framing. Therefore, entrepreneurs need to be resourceful both materially and cognitively to frame a problem based on scientific knowledge with the intention of intervening to solve it $[58,67,68]$. Entrepreneurs also need to frame a problem strategically if they are to build common meaning among institutional actors. Garud et al. [29] suggested that this can be done by narrating the problem using linguistic and cultural materials (e.g., non-technical and contextually relevant language) to avoid uncertainty around the framing of SLR problem.

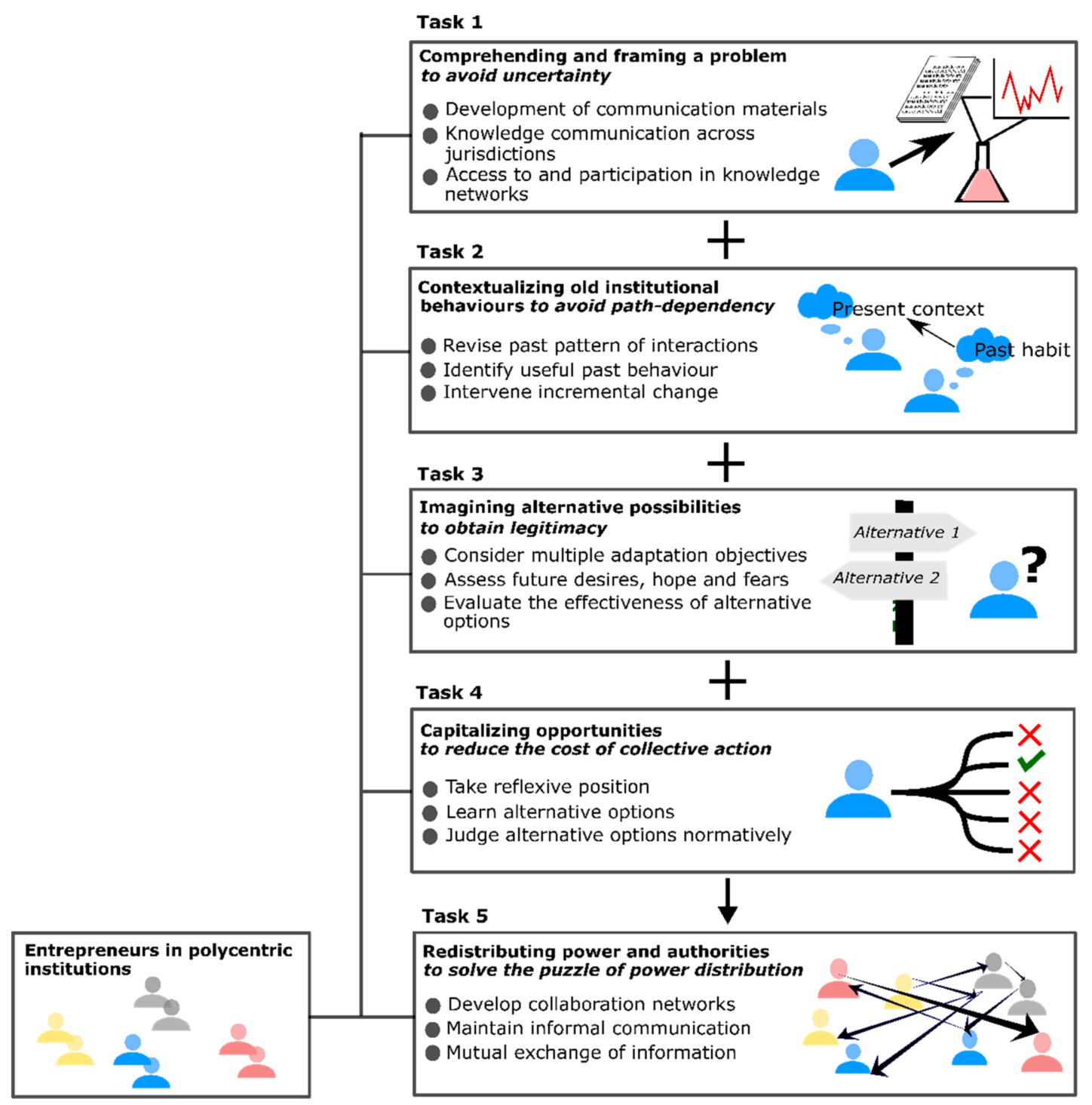

Figure 1. Institutional innovation to avoid institutional inertia through institutional entrepreneurship for NbCA. (Note: institutional entrepreneurs need to accomplish Task 1 to Task 4 to intervene for Task 5).

Secondly, institutional entrepreneurs must keep the proposed institutional change relevant to old behaviours. To be changed in support of tackling SLR, institutions need to be transitioned from past patterns of internal interactions among institutional actors, processes for SLR problem framing (e.g., flood, coastal erosion) and ways of responding to the problem (e.g., building protective structures) to new patterns of interactions [29]. In other words, Garud et al. [29] suggested that institutional entrepreneurs need to re-contextualize "past habits" into present adaptation decisions and actions. Emirbayer and Mische [63] identified this contextualization of past as the iterational element and 
explained it as "the selective reactivation by actors of past patterns of thought and action, as routinely incorporated in practical activity, thereby giving stability and order to social universes and helping to sustain identities, interactions, and institutions over time" (p. 971). The iteration of past habits is required to adjust institutions via incremental change, rather than risk breaking them. To iterate elements in institutional change, Emirbayer and Mische [63] suggested that entrepreneurs need to single out which past interactions and experiences are related to the present climate change impacts, what institutional practices need to be changed, what should be maintained and recognize the potential for past experiences to reoccur for the entrepreneur and other actors alike. Thus, the contextualization of past experiences helps maintain the habitual structure of institutions over time, which is often deemed necessary for overcoming path-dependent institutional inertia without radically transforming the general hierarchy and order of institutions.

Thirdly, entrepreneurs must imagine new ways of doing things. Problem framing helps the entrepreneur evaluate existing adaptation strategies and their efficiency to address SLR challenges, considering short- and long-term adaptation goals. If the existing strategies are found to be inadequate and unsustainable, alternative possibilities of adaptation are imagined. According to Emirbayer and Mische [63], alternative possibilities entail "... ... the imaginative generation by actors of possible future trajectories of action, in which received structures of thought and action may be creatively reconfigured in relation to actors' hopes, fears, and desires for the future" (p. 971). For example, NbCA is supported by many because of its cost effectiveness, long endurance and capability for sustainably generating multiple services along with coastal protection (e.g., biodiversity conservation, creation of economic opportunities, maintaining socio-cultural aspects of coastal systems, carbon sink potential etc.) $[13,23,69,70]$. The carbon sequestration potential alone is motivating many governments to opt for nature-based adaptations to help fulfil their long-term climate mitigation commitments [71-73]. Adaptation approaches like $\mathrm{NbCA}$ receive wider legitimacy if they can relate with other institutional commitment along with showing effectiveness toward managing future SLR risks [29].

Fourthly, entrepreneurs must be analytical to capitalize opportunities in the face of uncertainty. Practical adaptation decisions are taken in a temporal context, where past habits (e.g., past adaptation actions) and future projections (e.g., future SLR projections) are contextualized in current institutional interactions. For example, preexisting sewage structures of the City of Philadelphia had been deteriorated by the city's internal population dynamics and found to be inadequate to drain excessive rainwater presumably caused by climate change. To bring sustainable change to the sewage system and to adapt to climate change, in 2007, a group of local organizations argued for expanding the city's green spaces, which could have absorbed the excessive rainwater. Only one of all the candidates then running for mayor in the city supported this alternative adaptation proposal. That candidate won and incorporated the proposal into the city's adaptation plan, which was later implemented [74]. This example indicates that institutional entrepreneurs need to be capable of taking a reflexive position to examine conventional adaptation practices and open to learning alternative adaptation options $[67,75]$. Emirbayer and Mische [63] identified this capacity as the practical evaluative element of an institutional entrepreneur who is capable of making ".... .. practical and normative judgments among alternative possible trajectories of action, in response to the emerging demands, dilemmas, and ambiguities of presently evolving situations" (p. 971). By including normative judgements among the variables considered, an institutional entrepreneur can make appealing arguments in support of his/her proposed adaptation approach, which eventually helps minimize the cost of building collective action among the actors-one of the factors required to overcome institutional inertia [49].

The final task for institutional entrepreneurs seeking to implement $\mathrm{NbCA}$ approaches is the redistribution of power, authorities, roles and responsibilities among implicated institutional actors to re-structure their interactions [38]. Koene [44] suggested that institutional change, even if it is formally constituted, may require a long time to gain acceptance among institutional actors. To overcome this barrier, institutional entrepreneurs need to develop collaboration networks through repeated interactions that help to build congruence and innovate collective actions [58]. Lawrence et al. [38] suggested that 
such collaboration needs to be non-hierarchical, although based on some form of legitimate authority: such collaborations are ideally joint ventures that build alliances among actors with diverse interests. In support of this view, Prell et al. [76] suggested that institutional actors' views on an environmental problem is shaped more by their informal network of communication than by their institutional affiliations and positions, meaning that the collaboration should be more decentralized and organic for mutual exchange of information [38,77]. Collaboration makes institutional actors aware of their capabilities to add to adaptation options, based on how institutional roles and responsibilities are distributed. That is the mechanism that helps entrepreneurs to solve the puzzle of power distribution, which may seem fuzzy if not contentious in crowded jurisdictional spaces like coasts. A newly evolved distribution of power may not be diffused widely at the beginning of institutional entrepreneurship, which, however, can be matured and enacted as a new institution with repeated replication and success-the ultimate objective of institutional innovation [38].

\section{Background of the Case Study: The North Onslow Marsh in Truro, Nova Scotia}

Nova Scotia is one of the most SLR vulnerable provinces of Canadian provinces. The province's $55,000 \mathrm{~km}^{2}$ are dominated by a peninsula, connected by an isthmus to the rest of Canada, and the large island of Cape Breton $\left(10,000 \mathrm{~km}^{2}\right)$, along with thousands of smaller islands. There are 13 different coastal ecosystems in Nova Scotia, one of which is the expansive intertidal mudflats and salt marshes of the Bay of Fundy coast. Many of these salt marshes were drained year-round and protected by dykes for agricultural use by Acadians-the French cultural group and the first European settlers in Nova Scotia. These dyked lands (later to be known as dykelands or marshlands) dominate the Fundy flood plain of Nova Scotia [78].

Truro is a small regional center of 12,000 residents located on the floodplain of the Salmon River that flows into the Bay of Fundy, much of which have been dyked for agriculture, although the dykes are now protecting residential, commercial and transportation infrastructure as well. The town hosts a textile factory (Stanfields Clothing) and numerous businesses to support the agricultural industry [79]. Demographically, the region is dominated by largely non-immigrant, native English speakers, barely $2 \%$ of Acadian descent. The employment opportunities in the town have shifted from agriculture (only $2-4 \%$ in 2016) to other sectors like retail, health care, manufacturing and education sectors in recent years [80]. This is reflected in a decline in active farming and the increased abandonment, or 'fallowing', of dykelands.

Truro is widely known for its flooding problems. Because of its geographic location, almost every year, this town experiences severe flooding from the co-occurrence of rainwater accumulation, high tides and ice jams, even without SLR and storm surges [81]. A computer simulation recently mapped flood events in Nova Scotia based on newspaper coverage in the Chronicle Herald from 1992 to 2015, revealing Truro as the Province's flood hotspot [82]. Historical occurrences of flood have inconsequentially slowed down floodplain development in the town, exposing the town's infrastructure and residents to repeated flood events [81]. This risk-development nexus in Truro has made it one of the most interesting cases to be studied, especially for climate emergency management in Canada [79,83].

Truro went through several flood studies carried out in 1971, 1983, 1988, 1997, and 2006, each inspired by major flood events, to identify potential solutions to the town's flood problem. Consistent with the 'command and control' wisdom of the time [84], all resulting reports maintained reliance on hard-infrastructure based solutions that included recommendations like raising and strengthening dykes, the constructing runoff storage dams, a causeway/tidal dam to 'cordon off' Cobequid Bay, or ice control berms, and approaches to improve drainage and reduce sedimentation such as viaducts, channel straightening and dredging [81]. However, the technology available during the earlier reports was not adequate to apportion the various causes of flooding, which reduced the effectiveness of recommendations made in the reports. Moreover, the cost involved in developing, maintaining and improving the hard protection infrastructure was a significant challenge for the town and the County 
of Colchester, despite having a healthy balance sheet compared to other adjacent towns [85]. Both technological uncertainty and financial inadequacy sought a more holistic approach to model the river system in combination with the stormwater system to help identify alternative flood management and adaptation approaches to protect the town from the growing SLR risk [86]. After a strategic assessment that included both ecological and engineering aspects of flood protection, the municipal and provincial level institutional actors have come to a common understanding that the flood risk of the town could begin to be decreased in part by restoring the Onslow salt marsh, which is ecologically identified as a tidal wetland given the type of vegetation that will re-establish itself. The salt marsh is located on the northern side of the town and has long been dyked [55]. In general, this study explores how the institutional actors worked collectively to redistribute roles and responsibilities to help implement a $\mathrm{NbCA}$ project in the absence of any policy.

\section{Methods}

This study involved both primary and secondary qualitative data. While the secondary data helped reveal authority hierarchies and the roles and responsibilities of different agencies and actors at various levels of governments (e.g., federal, provincial and municipal), primary data collected from the identified institutional actors helped us explain how institutional innovation helped implement the Onslow salt marsh restoration project.

\subsection{Data Collection}

According to Mason [87], qualitative research data should not only be strategically collected but also need to be flexible and reflexive to the changing context of the study area, which is particularly relevant to studying institutional change. Thus, we conducted two levels of data collection to understand how the institutions managing the coastal systems of Nova Scotia are responding to the changing climatic and SLR problems of Truro. In the first level of data collection, we thoroughly studied municipal, provincial and federal policy and legal documents to collect data on the authority hierarchies of coastal management and the roles and responsibilities of different institutional actors distributed at different levels of the government (see Table 1 for the list of documents). 
Table 1. Legal documents analyzed for secondary qualitative data.

\begin{tabular}{|c|c|c|c|c|}
\hline $\begin{array}{l}\text { Policy Instrument (Acts, } \\
\text { Policies, Plans) }\end{array}$ & Year of Enactment & $\begin{array}{l}\text { Government Level (Federal, } \\
\text { Provincial, Municipal) }\end{array}$ & Primary Enforcement Agency & $\begin{array}{c}\text { Jurisdictions in Coastal Protection } \\
\text { Areas }\end{array}$ \\
\hline $\begin{array}{l}\text { The Agricultural Marshland } \\
\text { Conservation Act }\end{array}$ & 2000 & Provincial & Department of Agriculture & $\begin{array}{l}\text { Dyke, dykelands and agricultural } \\
\text { marshlands }\end{array}$ \\
\hline The Municipal Government Act & 1998 & Provincial & Department of Municipal Affairs & Municipalities \\
\hline The Beaches Act & 1989 & Provincial & Department of Natural Resources & Beaches \\
\hline The Crown Lands Act & 1989 & Provincial & Department of Natural Resources & Provincial crown lands \\
\hline The Trails Act & 1989 & Provincial & Department of Natural Resources & \\
\hline The Endangered Species Act & 1999 & Provincial & Department of Natural Resources & Wildlife habitats \\
\hline The Conservation Easements Act & 2001 & Provincial & Department of Natural Resources & Private land owners \\
\hline The Provincial Parks Act & 1989 & Provincial & Department of Lands and Forests & $\begin{array}{l}\text { Crown lands designated as provincial } \\
\text { parks and park reserves }\end{array}$ \\
\hline The Environment Act & 1994-1995 & Provincial & Department of Environment and Labour & Coastal and wetland areas \\
\hline $\begin{array}{l}\text { The Environmental Goals and } \\
\text { Sustainable Prosperity Act }\end{array}$ & 2007 & Provincial & Department of Environment and Labour & Wetland areas \\
\hline Wilderness Areas Protection Act & 1998 & Provincial & Department of Environment and Labour & 30 designated wilderness areas \\
\hline The Canso Causeway Act & 1989 & Provincial & $\begin{array}{l}\text { Department of Transportation and } \\
\text { Infrastructure Renewal }\end{array}$ & Causeway at the Strait of Canso \\
\hline The Off-highway Vehicles Act & 1989 & Provincial & $\begin{array}{l}\text { Department of Transportation and } \\
\text { Infrastructure Renewal }\end{array}$ & $\begin{array}{l}\text { Off highway crown lands including } \\
\text { sensitive areas like wetlands, wilderness } \\
\text { beaches and dunes }\end{array}$ \\
\hline Special Places Protection Act & 1989 & Provincial & Department of Tourism, Culture and Heritage & $\begin{array}{l}\text { Coastal areas with archaeological, } \\
\text { historical or palaeontological significance }\end{array}$ \\
\hline The Fisheries Act & 1985 & Federal & Department of Fisheries and Ocean & Offshore and wetland fishing grounds \\
\hline The Ocean Act & 1997 & Federal & Department of Fisheries and Ocean & \\
\hline Municipal by-laws & - & Municipality & Municipal governments & Municipal land use \\
\hline Marsh Body by-laws & - & Marsh bodies & Marsh bodies & Marsh sections \\
\hline
\end{tabular}


To deal with the Coastal Protection Act, which is now in the process of being enacted, we had to depend on the comments of the few research participants who were involved in the development of the Act. It has been bemoaned that "Nova Scotia has at least 45 pieces of international, federal, provincial, and municipal legislation that deal with its coastal resources". We analyzed the 18 legal and policy documents most relevant to this study. The document analysis helped us to identify the actors who are directly and indirectly related to the coastal management of the province and who were to be interviewed in the next level of data collection.

The next level of data collection involved in-depth semi-structured interviews of the institutional actors selected based on the document analysis and the type of data required for understanding institutional innovation [88]. A semi-structured interview is one of the most commonly used and flexible qualitative data collection approaches [89]. Along with the document analysis, we identified interviewees based on our personal knowledge of the field [58]. The last author of the paper has a longstanding partnership with and active engagement in the province's coastal system management institutions. Considering our theoretical assumption that an institutional entrepreneurship is intervened by a few resourceful institutional actors [58], we conducted semi-structured interviews with 10 people in 2018 to provide more clarity on the institutional interactions of the case study. The interviewees included all the key provincial and municipal government officials, local community representatives and engineering and climate adaptation consultants involved in implementing the project. Each interview had 8-10 open ended questions customized for each interviewee based on their institutional positions and roles and lasted for 1-1.5 h, save one which proceeded by emailed responses to written questions. These interviewees were all seen as experts whose work made them responsible authorities on the project, appropriate to answer factual questions, and so this was not seen to attract ethical oversight. That said, we certainly did proceed ethically, providing full transparency at the time of first contact (including supplying questions, if requested), asking for verbal consent, including to record, and clearing specific quotes. Interviewees agreed for any quotes to be attributed to their position name rather than their given name and approved the context in which their quotes were used, although we do not draw heavily on quotes here. The interview data were analyzed as described below to test and refine our emerging framework.

\subsection{Data Analysis and Triangulation}

This study involved two levels of data analysis: (i) narrative account of coastal system and flood risk management institutions and (ii) description of initiating $\mathrm{NbCA}$ action in the study area through the redistribution of roles and responsibilities of the institutional actors. These were validated through a participatory workshop.

In the first level of data analysis, we critically analyzed legal and policy documents to understand the Canadian governments' policies to manage coastal systems and what government agencies (i.e., federal, provincial and municipal) are involved in coastal flood management. This allowed us to map the institutional terrain of coastal jurisdictions and understand how coastal land and resources are managed. This analysis also discerned the legally distributed roles and responsibilities of the institutional actors and the legally endowed rights, roles and responsibilities of local communities in managing land resources, land use practices, and flood risk management.

The second level of analysis involved synthesizing the interviews for overall storyline and deductively based on entrepreneurial tasks described in the Institutional Innovation for $\mathrm{NbCA}$ section: identify and explain opportunities for implementing $\mathrm{NbCA}$ in the study area; contextualize and frame flood problems; develop implementation plans; and convey the plans for persuading competing actors and distributing responsibilities without violating existing legal provisions [90], While synthesizing and analyzing the data, we also took account of (i) who is telling? (ii) about what event? (iii) when? and (i) what is happening at present; and (ii) why?-some of the key questions necessary for ensuring analytical rigor [90]. 
Mason [87] emphasized that a qualitative data analysis needs to be rigorous, which can be obtained by the validation of data analysis. According to Flick [91], methodological triangulation is a process of validating qualitative insight usually conducted by using an alternative data collection method at different times, in different places or from different people. The validation of data analysis was of particular interest to this study because of the small number of interviewees. Therefore, we validated the outcomes of our data analysis by presenting them in a daylong participatory workshop organized in the fall of 2018. This method helped us avoid the complexity of analyzing data from multiple sources, since the participants were allowed to provide feedback directly on the outcomes, which Momsen [92] identified as a useful tool for correcting mistaken assumptions. We invited 30 participants to the workshop. Along with the 10 interviewees, we invited representatives of environmental activist groups, NGO personnel, Indigenous and other community representatives, academicians and government officials who were not included in the primary data collection. After describing the conceptual background of $\mathrm{NbCA}$ and our study in the first session of the workshop, we presented the outcomes of our study for questioning and open discussion by the participants to examine if our interpretation was correct. This practice yielded some minor modifications to our analysis.

\section{Results}

Coastal flood risk management in Canada involves a complex governance process that stretches from federal government to municipal governments along with the involvement of private land owners (Figure 2). Until the 1940s, Nova Scotian dykes were developed, maintained and managed by the collective initiatives of private dykeland owners-also known as Marsh Bodies (see below for specific definition)—led by an elected commission responsible for governing dyke and dykeland management works. The management authority of the dykeland owners was legalized by the provincial government of Nova Scotia in 1760 [93]. However, some repeated flood and storm events that occurred during the 1930s influenced the federal government to take over the responsibility of managing the dykes in the country's Atlantic provinces. Since then, the management and maintenance of dykes and dykelands have been formalized and distributed among different government agencies, later to be evolved to a complex fabric of institutional process.

\subsection{Multilevel and Polycentric Institutions for Coastal Flood Management}

\subsubsection{Roles and Responsibilities of the Federal Government Agencies for Coastal Flood Management}

The formation of the Maritime Dykeland Rehabilitation Committee in 1943-a joint initiative of the provincial governments of Nova Scotia and New Brunswick and the federal government-was the first government initiative that took dykeland management activities under a single ongoing program. The committee was comprised of four dykeland owners, four engineers, one soil specialist and a federal government representative, to which the collectives of dykeland owners could appeal for dyke rehabilitation support. The committee completed 80 rehabilitation projects in Nova Scotia with expenses distributed among the federal and the provincial governments and the dykeland owners. This was a small share compared to the tasks yet to be completed. In response, the federal government enacted the Maritime Marshland Rehabilitation Act in 1948 to create the Maritime Marshland Rehabilitation Administration, which, by 1960, completed all major dyke construction and reinforcement works and gradually handed over the dykeland management responsibilities to the provincial governments between 1967 and 1970. However, outside the dykes, all activities in the exclusive economic zone (i.e., 200 nautical miles from mean low tide mark) remained under the federal jurisdiction and different agencies and acts regulate these activities along with keeping custody of crown lands and First Nations affairs.

The federal government still plays an active role in coastal flood risk management. In 1975, the federal government initiated the Flood Damage Reduction Program (FDRP) in collaboration with all provincial and territorial governments to help identify and designate flood risk areas and 
to encourage the provincial governments not to build, approve or finance any new development in the designated zones. A nationwide mapping scheme identified and designated the flood risk areas in 900 communities under a mapping agreement between the federal, provincial and territorial governments. These agreements also aimed at discouraging the provincial governments to build costly flood protection structures (e.g., dykes, dams) unless preventive and non-structural options are available. Since that time, the federal government has been facilitating flood protection activities with the provincial governments performing key decision-making roles.

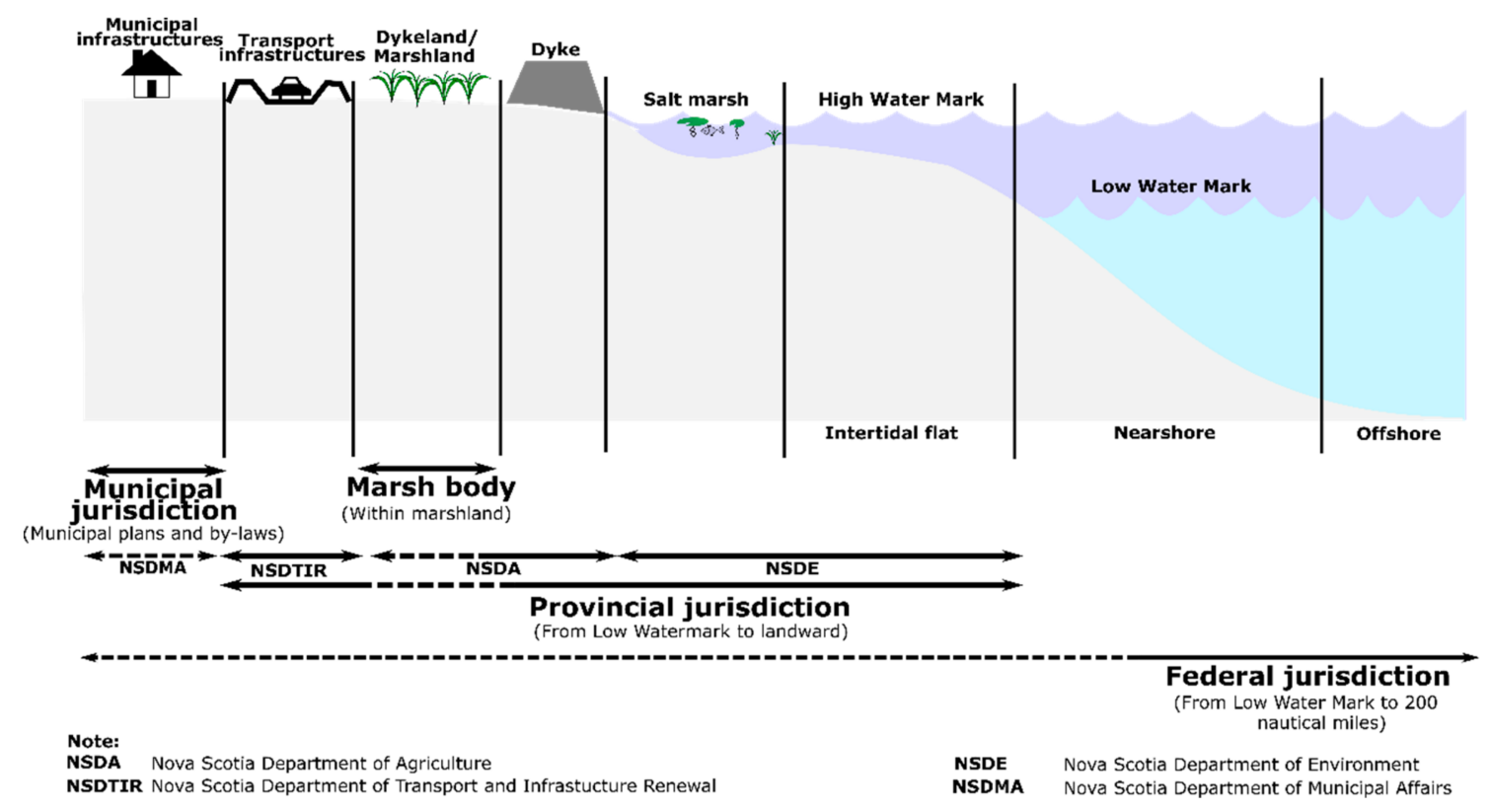

Figure 2. Coastal jurisdictions of Nova Scotia (Note: the solid double-headed arrows indicate direct control on decision making and dotted double-headed arrows indicate no direct control on decision making).

5.1.2. Roles and Responsibilities of the Provincial Government Agencies for Coastal Flood Management in Nova Scotia

The provincial government distributes its dyke and dykeland management responsibilities to different agencies for the successful implementation of multifaceted management tasks. For example, the Nova Scotia Department of Agriculture (NSDA) is responsible for managing and maintaining the province's 260 aboiteaux (i.e., gates that drain water) and $241 \mathrm{~km}$ of dykes under the Agricultural Marshland Conservation Act, 2000. The minister of Agriculture can decide on developing, maintaining, improving and protecting dykes and dykelands, subjected to the approval of the Governor in Council. The Governor in Council can appoint an Agricultural Marshland Conservation Commission to advise the Minister of Agriculture about dyke, dykeland and marshland protection and maintenance. This Council also hears appeals subjected to this act and approves by-laws made by the marsh body (see the next Sub-section for detail). On the other hand, the Minister can appoint a Marshland Administrator, who is responsible for performing duties assigned by the Act. Proposed changes to dykelands must also be cleared with the Nova Scotia Department of Communities, Culture and Heritage (NSDCCH), which is responsible for archaeological resources-including Acadian dykes as well as other resources found in areas protected by dykes-designated by the Special Places Protection Act, 1989 [94]. The Nova Scotia Department of Lands and Forestry (NSDLF) is the custodian of 94 beaches designated as protected under the Beaches Act, crown lands and provincial parks, trails on lands and over watercourses, conserving endangered species and wildlife habitats except fish species regulated by the Nova Scotia Department of Fisheries and Aquaculture (NSDFA). The Nova Scotia Department of Environment (NSDE) is the custodian of all provincial wetlands and responsible for developing 
provincial adaptation and mitigation strategies. The Nova Scotia Department of Transportation and Infrastructure (NSDTIR) does not have direct jurisdiction or authority on coastal land and resources. However, according to the province's wetland conservation policy, any loss of freshwater wetland or salt marsh due to road and infrastructural development needs to be compensated by restoring new habitat, many of which help to mitigate the coastal flooding problem. The Department needs to release technical and financial support to comply with this policy, making it one of the key players in coastal adaptation decision making.

\subsubsection{Municipal Government}

According to the Municipal Government Act, 1998, every municipal government can develop respective Municipal Planning Strategies (MPS) - a document that contains detailed layouts of existing infrastructure and admissible future development along with other land use practices (e.g., agriculture, recreation). The planning strategies are guided by the Statements of Provincial Interests-a provincial guideline for developing the MPSs and land use by-laws, covering five broad areas, including drinking water, flood risk areas, agricultural land, infrastructure and housing. To date, 40 out of 51 municipalities have developed their comprehensive strategies, while 11 municipalities have single issue coverage. In particular, the flood risk areas guidelines guided by the Nova Scotia-Canada FDRP have identified five river basins in the province, along with designating high-flood areas. In general, the municipal governments' role is limited to managing inland development and land use management activities.

\subsubsection{Marsh Body}

A Marsh Body is a collective of marshland (or dykeland) owners who petition to the Marshland Conservation Commission to be incorporated as a governing body for a marshland section "(an area of marshland that may be effectively dealt with as a unit in the construction and maintenance of works" - the Agricultural Marshland Conservation Act, 2000). This Body can acquire, sell and lease personal property, and can decide on constructing and repairing dykes on its own expense or in an agreement with the Minister of Agriculture. This Body also makes by-laws, which are subjected to the approval of the Commission. The Body needs to have an executive committee to perform the administrative activities and to assess the value of marsh and dyke lands. Notably, the chair and secretary of the committee are endowed with the authority equal to the mayor and treasurer of a town provided by the Municipal Government Act to decide on any activity (e.g., dyke restoration, drainage maintenance). The executive committee is supervised by the Governor in Council, who can suspend the authority of the committee, should the committee cause any permanent injury to the marsh and dyke lands. The Governor in Council can, therefore, revert the activities and authority of the committee to the Marshland Conservation Commission. According to the Agricultural Marshland Conservation Act (2000, c.22, s.13b), the government needs consultation with and agreement by two-thirds majority votes of a Marsh Body to alter the boundaries of their marshland.

\subsection{Institutional Innovation for Coastal Adaptation: The Case of Onslow Salt Marsh Restoration, Truro}

The stable institutional structure described above, which has evolved through a historical process, is designed for 'hard' solutions, such as dykes, berms, and shoreline armoring [95], but these solutions are beginning to fail under SLR and storm surges $[79,96]$. In line with growing global attention to ecosystem- and nature-based alternatives to hard infrastructure $[15,24,97]$, small-scale experiments in living shorelines and salt marsh restoration have been underway locally, led by NGOs and environmental consultants in partnership with universities under the supervision government agencies [98]. However, relatively larger-scale implementation of $\mathrm{NbCA}$ through appropriate policy and institutional design is scarce in Canada. This section describes how the institutional actors of the provincial government of Nova Scotia have used collective action to restore the Onslow salt marsh for minimizing the coastal flood risk of the Town of Truro as one of the goals of the Onslow salt marsh restoration project (Figure 3). 


\subsubsection{Problem Framing: The Coastal Flood Risk of Truro}

Truro was one of the high-risk areas identified by the FDRP and the federal government notified the town after a study in 1988 that the flood affected communities would only get one more damage payment, after which those would cease. This was the federal government's legal measure to inform the local residents about flood risks and their responsibilities to protect themselves. However, such decisions are politically difficult to sustain and have never been, which encouraged the municipal government to look for the protection options that were assumed to be more assured and publicly accepted.

Until Tropical Storm Leslie in September 2012, flood risk management at the municipal level was based on hard-infrastructures and soft legal measures (e.g., dyke maintenance, culvert sizing and new development regulations). In that fall 2012 flood, a privately-owned dyke on the North River that used to protect numerous businesses breached in several places. Local politicians and affected citizens, all apparently unaware that dykes were largely built for agricultural land uses, called for repairs and reinforcement to the dyke system (i.e., 'topping', or building it higher) to the provincial government. Given future rain forecasts, the province performed repairs for emergency management purposes, although the responsibility for ongoing maintenance of this dyke was unclear.

A Joint Flood Advisory Committee was created in 2012 for the County of Colchester, Town of Truro, and Millbrook First Nation, including community and provincial government representation. The Joint Flood Advisory Committee commissioned a comprehensive flood risk study of Truro conducted by consulting engineers CBCL Limited. The CBCL team developed a set of hydrodynamic computer models out to 2100 to understand the relative influences of rainfall, river hydrology, tides, sedimentation and ice movements using detailed terrain maps derived from Lidar, bathymetric surveys, field measurements and imagery from multiple aerial platforms [99]. Once these dynamics were understood, the team modelled a number of flood mitigation options and ranked them using stakeholder-derived human, land use and infrastructure priorities, the protection level that each provided (including in extreme events), its initial and life cycle cost, the value of the land protected, and feasibility given environmental and permitting requirements [81].

\subsubsection{Contextualizing Past Habits and Futures Projections in Present Decision Making}

Land use practices in Truro have been shifting from agriculture to manufacturing to housing industries; thus, flood protection priorities have also been shifting. A stakeholder consultation-based prioritization by the $\mathrm{CBCL}$ engineering team reported similar observations, ranking agricultural lands and dykeland infrastructure maintenance at sixth position, while residential land use ranked second. Notably, water-front housing and infrastructures in Truro, unlike many other coastal cities in the world, have been developed not because of market incentives like increased amenity. Rather it was a historical continuation of early development along shorefront and riverfront roads, and the desire by the municipalities to capitalize on the economic development opportunity of passing highway traffic.

The flood report confirms that the multiplicity of causes makes the flooding problem in Truro complex and no single solution was found to be cost effective and technically efficient at the same time. For example, protection for more than $20 \%$ of the priority areas requires almost $\$ 100 \mathrm{M}$ accompanied by intensive earthworks (e.g., river straightening, floodway bypass) and maintenance (e.g., dredging). Like in previous flood studies (see Section 3), renovating and raising dykes to $6 \mathrm{~m}$ high in some places with corresponding design challenges to widen the base was found to be most effective, although the most costly option, and needed to be accompanied by specialized pumping for protecting $30 \%$ priority areas at a cost of $\$ 300 \mathrm{M}$. Additional aboiteaux construction, as considered in the 1970s to hasten drainage, was also modeled as an option and found to be ineffective. Although the aboiteaux could protect some areas from storm surges, they may potentially hold in rainwater and/or increase sedimentation. The other option, dyke breaches, could actually reduce flood risk, but would require raising priority non-residential areas and roadways, and purchasing homes for removal or relocation. This option might cost around $\$ 200 \mathrm{M}$ along with the risk of civic conflict for relocating properties and public infrastructure. Considering the inadequacy of the options described above, CBCL was 
asked to provide an infrastructure-based recommendation ready to submit for available funding opportunities. The most efficient recommendation was floodplain restoration by realigning dykes and re-establishing salt marsh for improving water storage capacity-an adaptation approach commonly known as 'managed realignment' in NbCA. This recommended option would cost $\$ 99 \mathrm{M}$, protecting $29 \%$ of priority areas. In general, the CBCL report provided a scientific basis for implementing NbCA as a flood mitigation measure and helped develop a common understanding for all institutional agencies directly and indirectly engaged in the measure.

The provincial government's climate action regulatory instrument-the Environmental Goals and Sustainable Prosperity Act, 2007-motivates provincial climate mitigation objectives like achieving renewable energy targets and enhancing adaptation and education activities, none of which specifies legal and institutional frameworks for implementing the NbCA approach suggested in the CBCL report. Yet, the regulatory instrument helped to create a Climate Change Unit within Nova Scotia Department of Environment (NSDE) to work with provincial departments and municipal governments to minimize GHG emission and help implement adaptation measures. Thus, most of the adaptation activities intervened under this act is facilitation and education. For example, an Adaptation Specialist at NSDE identified themselves as 'adaptation-capacity builders', and in the absence of any regulatory requirements, to adapt, they have only the power of persuasion at the time of project planning and implementation. The Adaptation Specialist at NSDE further explained the logic of their capacity-building approach in a weak climate policy context:

I don't think there is a department in government whose core work is not being touched by some aspect of climate change ... but that's not really very well reflected in the operational plans or policies in many departments, and so ... if we're waiting for someone to have that word in their mandate or job description, really nobody does that, and that doesn't really get us anywhere.... Part of the reason we developed the approach we did, which is really trying to focus on the context in which each department is working, is that, it can build in more commitment and engagement than if it becomes a government edict. We think it's a robust approach.

Therefore, this indicates that the standalone approach of the provincial government's agencies is not adequate to deal with the potential future flood problem, which spurred the necessity of building an alternative institutional approach that could make the implementation of the adaptation action possible. However, such an approach needed to be built on the common interests of the agencies, for which, according to the NSDE Adaptation Specialist, the institutional actors had to go beyond their respective institutional roles and responsibilities to consider alternative options.

\subsubsection{Finding Opportunities: Juxtaposing Multi-Agency Interests}

As a custodian of provincial wetlands under the Environment Act, 1994-1995, NSDE, works on identifying and protecting salt marshes as wetlands of special interests, supported by the Wetland Conservation Policy, 2011. Reversing historic wetland loss and maintaining the no-net-loss of wetlands due to infrastructure development are at the core of the policy. Thus, a compensation strategy has been proposed, depending on the type and quality of destroyed and gained wetland due to the construction works. As the policy suggests, no salt marsh should be destroyed but if it is, one hectare of fresh water wetland or four hectares of salt marsh would be needed to compensate for one hectare of salt marsh loss. On the other hand, two hectares of fresh water wetland is required to be compensated for one hectare of fresh water wetland loss. However, salt marsh, wetlands in parks or drinking water catchments are preferred for wetland compensation due to the historic loss of salt marshes in Nova Scotia estimated at about $85 \%$ on the Bay of Fundy, and restoration is more preferred than creation as the later often fails.

Most of the construction works that affect natural habitats like salt marshes are usually done by NSTIR due to road construction and infrastructure maintenance. Many of their maintenance and construction activities that require hardening of land surfaces and heightening infrastructures in 
the face of SLR exacerbate 'coastal squeeze' (for detail see $[100,101]$ ) - a development footprint that 'rebounds' (see Juhola et al. [18]) coastal vulnerability. Therefore, NSTIR needs to release financial and technical resources for the restoration of salt marshes to comply with the NSDE imposed regulations and development standards. Our interview data also reveal that the Senior Environmental Scientist of NSDTIR had a motivation to create ecologically attractive large-scale restoration sites which could be used as a carbon sequestration opportunity. NSDLF, although it does not have jurisdiction over wetlands unless they are located in provincial parks, is also interested in wetlands for the habitat functions they provide for waterfowl, for instance, via the Eastern Habitat Joint Venture of the North American Waterfowl Management Plan. On the other hand, NSDA, as a responsible body to maintain and develop dykes in the Bay of Fundy region, were finding dyke maintenance activities highly expensive in the face of climate change. As mentioned above, some Truro dykes were no longer under use for the protection of agricultural land, rather, they were perceived as a protection for residential and commercial areas, which is not a function of NSDA.

In addition to the regulatory opportunities, a new opportunity emerged when this restoration project was nominated as a part of climate adaptation training, and the Environmental Analyst of NSDTIR, along with the then-Director of Land Protection of NSDA, intervened to be 'adaptation champion' in collaboration with the Climate Change Unit of NSDE. Working with the government departments individually until 2014, the Unit helped develop softer skills like planning and communication. Being in the same training program, the department representatives had an opportunity to come around the same table as departmental 'adaptation champions', allowing them to obtain "social license in their departments to get the project achieved" (NSDE Adaptation Specialist).

Therefore, a proposed Onslow-North River Dyke realignment project created three opportunities for the involved government departments: (i) reduce ongoing dyke maintenance costs for NSDA by reducing the total length of dyke and number of aboiteaux; (ii) enhance the protection of both public and private infrastructure, as well as viable farmland; and (iii) reduce flood risk and enhance resiliency for climate change through the restoration of floodplain, one of several actions recommended by the 2017 Flood Risk Study.

\subsubsection{Redistributing and Performing Roles and Responsibilities for Implementing $\mathrm{NbCA}$}

NSDTIR has developed a strong and long-enduring network with non-government actors and agencies for implementing wetland compensation activities. This network is built upon an industry-academia collaboration-an example of non-governmental initiative not commonly observed in climate adaptation action. As a continuation of this network, NSDTIR commissioned CB Wetlands and Environmental Specialists (CBWES), in partnership with Saint Mary's University (SMU) and Queens University (QU) in December 2016, to realign Truro dykes to implement a restoration design plan for the 'northern parcel' of the Onslow-North River Dykeland. The restoration works involved working with NSDA and local Marsh Body to determine an optimal location for new dykes and construction materials, identifying the location and size of breaches in the old dyke, creating a restoration design for the tidal wetland, and anticipating habitat responses to restoration (Figure 3). 


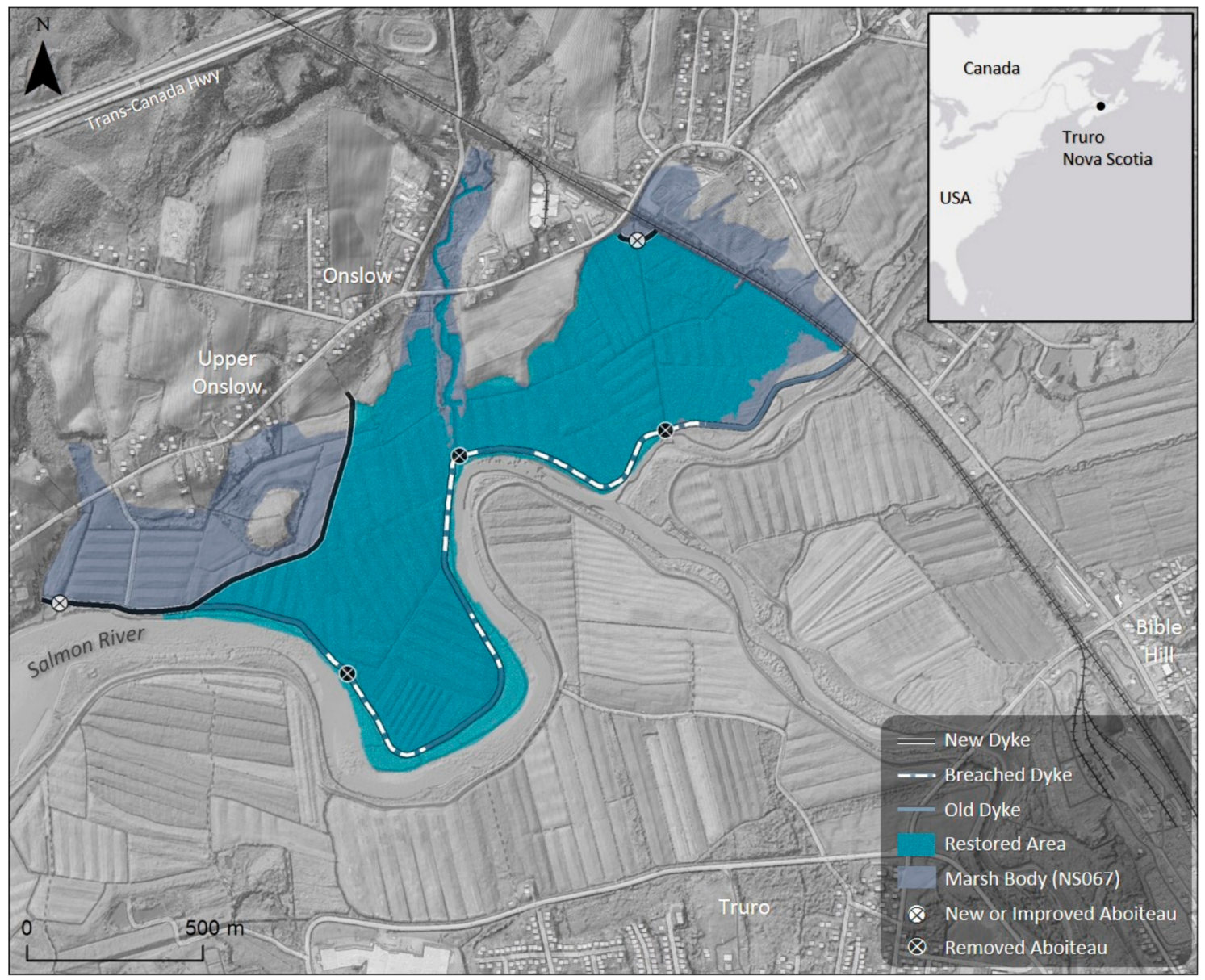

Figure 3. The North Onslow marsh body being modified (grey), with area to be restored (blue), aboiteaux to be removed (black) and new/improved (white), old dyke (blue with dotted lines where to be breached), and new dyke (black lines) (Source: Raymond Jahncke, Will Flanagan, Saint Mary's University Department of Geography and Environmental Studies).

Despite the preparation taken by both government and non-government agencies, the implementation of the project was far from simple, as additional redesign of the project was required and the project implementation actors needed to balance the project with other land use requirements. The Canadian National rail line defines the eastern border of the project site; the 1763 Onslow Island Cemetery is within its western boundary and a power transmission line dissects the site. Consultation with CN Rail and Nova Scotia Power was necessary to address any potential risks to their respective infrastructure either through the inclusion of flood protection measures or their relocation, but though notified along with other landowners they were late to join the planning table. In anticipation of the project, NSDTIR purchased the majority of the dykeland property needed for the project in 2016, yet several parcels adjoining the floodplain had not been purchased, for which additional flood vulnerability was assessed, and mitigation actions would be recommended as part of the design. NSDA staff performed a mediator's role, consulting with neighboring land owners to ask if they were interested in purchasing the land before it was bought by NSDTIR. Those neighbors declined, saying that the land is prone to freshwater flooding. Such an 'informed consent' based approach taken by NSDA helped the project to avoid a competition in land market that could have risen a conflict with local communities (Figure 4). 


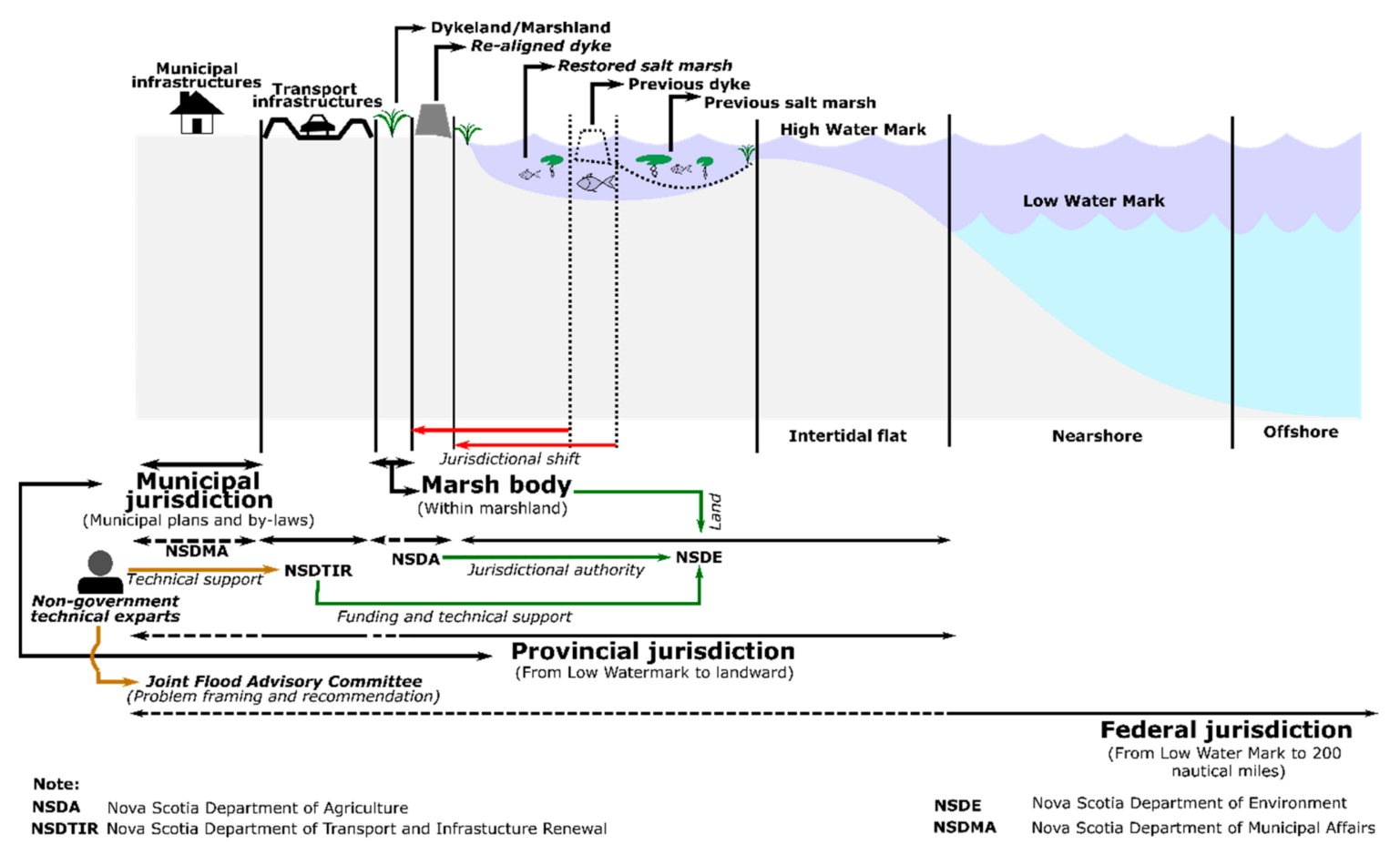

Figure 4. Redistribution of roles and responsibilities for salt marsh restoration as a $\mathrm{NbCA}$ initiative (Note: The solid double-headed arrows indicate direct control on decision making and the dotted double-headed arrows indicate no direct control on decision making).

In accordance to the Marsh Land Act, the project implementation actors consulted with the members of the local Marsh Body and bordering landowners, where the invited members were introduced to the project and engaged in project planning process. A series of community hall type meetings, a special topic meeting, and 'kitchen table' conversations with individual stakeholders were organized by the project implementation team with an aim to obtain not only their agreement but also their support for the project. However, the Onslow Marsh Body was not 'active', which one of the respondents of this study identified as a common feature in Nova Scotia. Therefore, the first step of consultation process involved the re-activation of the Onslow Marsh Body and to provide them with the structure, information and tools needed to effectively participate. NSDA, as the provincial agency responsible for the Marshlands and Marsh Bodies, took up the charge of re-activating and engaging the Marsh Body members in the planning process. NSDA invited all landowners within the NS067 Marsh Section to a meeting on 6 June 2017, to discuss "salt marsh restoration and climate change upgrade for Onslow North River Marsh".

That first Marsh Body meeting attracted about 10 individuals, a good proportion of property owners including representatives of institutional landowners like the Municipality and NSDTIR. The idea and rationale for the project was presented during the meeting, which encountered two challenges: first, many of the participants asked about alternative solutions to the flooding problem, which were difficult to debunk as the Truro flood study report was not yet publicly available; and the second challenge was difficulty in interpreting the flood modeling maps. At the end of this meeting, it was agreed that a second meeting would be held three weeks later during which new realignment and restoration designs would be presented that reflected the feedback in the first meeting.

The second meeting was held on 27 June 2017 with a similar size and started with a summary of the first meeting and the presentation of the draft realignment options. The project team explained most of the questions raised during the first meetings and the new queries put forward in the second meeting. For instance, Marsh Body members asked how this project could lead to decreased cost as the upfront investment is so high. The team explained that the long-term maintenance cost for the original length of the dyke $(3 \mathrm{~km})$ and aboiteaux (4 in number) would exceed the cost of the proposed project, 
which is cost-shared with NSDTIR. Marsh Body members also asked why the plan was to move the dykes back, rather than straighten the river to reduce floods. The team answered that straightening the river is not legal under the Federal Fisheries Act, nor is it technically effective. However, some questions could not be adequately answered within the meeting as they required additional research, refinements to the design and validation by the hydrodynamic modeling. For instance, how would restoring the floodplain affect flooding, both at the immediate local level and for the broader town of Truro? What would the site look like following breaching of the old dyke; would it become an unsightly mudflat? These answers were brought back to the Marsh Body after further investigation and collection of case study materials from other restorations carried out by CBWES. Another concern raised in the meeting was the issue of mosquitoes, which was to be answered during a third meeting.

The third meeting was held on 17 September 2017, and involved an elected sub-group of Marsh Body members and the Curator of Zoology of the Nova Scotia Museum and General Director of the Greater Moncton Pest Control Commission was invited-the subject matter experts from the region on the mosquito issue. The experts explained how they monitor and regulate mosquitoes in a tolerable limit using both ecological and technical measures as well as that higher biodiversity and lower standing water in salt marshes reduces the risk of mosquitos.

The final meeting called by the Chair of the Marsh Body was held on 24 October 2017 to conduct a vote of the Marsh Body members according to the Marshland Act, to obtain the members' agreement on the proposed project. Prior to the vote, the proposed dyke realignment design was presented and all remaining questions were answered. The Marsh Body members voted for the project unanimously, with two caveats: (1) that a pest-management protocol be developed as part of the project, including monitoring, and (2) that ongoing communication with the Marsh Body be maintained.

\section{Discussion and Conclusions}

$\mathrm{NbCA}$ is a new approach to minimizing the negative impacts of SLR in coastal social and ecological systems. However, the implementation of such approaches under a historically developed institutional structure, often designed for hard-infrastructure-based coastal protection, is difficult. Building on a case study derived from one of the most SLR vulnerable provinces of Canada, this study intends to explain how innovative institutionalization can help implement the $\mathrm{NbCA}$ approach in the absence of regulatory and policy guidance. Drawing on the institutional entrepreneurship literature, the case study shows that an intervention for implementing NbCA may develop if institutional actors come to a common agreement to redistribute roles and responsibilities based on the entrepreneurial use of scientific information, legal and procedural opportunities and inter-organizational cooperation. Before concluding, we present five lessons for implementing $\mathrm{NbCA}$.

First, building knowledge networks on SLR vulnerability and solution options helps develop a common agenda for adaptation decision making [66]. It is evident from the case study that the Truro flood study spurred discussion towards an alternative adaptation approach that could also serve other pro-environmental commitments of the Nova Scotia governments. The cost-benefit analysis and long-term effectiveness of different alternative adaptation approaches reported in the flood study identified salt marsh restoration as the most immediately viable option. Using advanced scientific tools and methods in this study, the consulting engineering firm (i.e., $\mathrm{CBCL}$ ) helped make it possible to reflect on both flood risk management approaches and future flood potential to inform the present decision-making context $[29,63]$. Interpreting the scientific knowledge in a non-technical language helped develop a common meaning and commitment for $\mathrm{NbCA}$ among the institutional actors, giving the approach a legitimized ground $[39,58]$. Moreover, the proposed salt marsh restoration project was further fine-tuned and customized by a group of scientists, practitioners, engineers, government officials and local communities, each bringing their technical, tacit and experiential knowledge. More specifically, the trust-based network that has emerged as a result of a long-term collaboration among scientists from SMU and QU, engineers and practitioners from CBWES and CBCL with the officials from NSDTIR, NSDA and NSDE creates an open environment for sharing views and ideas for 
building an operational language among the actors. Rahman et al. [45] suggested that assembling and accumulating multiple sources of knowledge help minimize the uncertainty of an action subjected to diverse legitimacy considerations of different institutional actors. Therefore, this observation reflects what Greenwood and Suddaby [53] explained as networking with peripheral institutional actors for institutionalizing the use of new technologies. They identified that being less embedded in existing institutional structure, the peripheral actors (i.e., scientists, practitioners, and communities) are able to offer new technical solutions to more institutionally embedded actors and can provoke them to break the path-dependent institutional nature of depending on hard-infrastructure-based adaptation actions.

Secondly, opportunity creation or recognition within the existing institutional structure is a key entrepreneurial activity for the successful implementation of NbCA [61,62]. NSDTIR, which is legally obliged to restore or create salt marshes as a compensation for their infrastructural development activities, found the suggested solution as an opportunity for their compensation activities. On the other hand, NSDA recognized this solution as an opportunity to minimize dyke maintenance cost, which was their legal responsibility, particularly where the dykes were no longer being used for agricultural protection. To capitalize on this opportunity, NSDA agreed to give up their jurisdictional authority on dykes and dykelands. NSDE, as the adaptation champion of the province, supported this opportunity to perform an effective role for both the province's climate adaptation and commitment for carbon sinking.

Thirdly, the distribution of roles and responsibilities for implementing a NbCA action needs to be based on the institutional capacity to release resources. The case study shows that NSDTIR, being a financially resourceful government agency, released funding for purchasing land and other operational activities, while NSDA handed over their jurisdictional authority and performed as a bridging agent between land owners and the project team (Figure 3). NSDA personnel were also most resourceful in terms or local knowledge, which helped the project designers to develop an optimal design for dyke realignment. Moreover, hosting the consultancy with land owners, NSDA helped the team to obtain the trust of residents and marshland owners and comply with legal procedures. NSDE, who had no direct jurisdictional authority on dykeland, was a bridging agent among institutional actors by bringing all relevant institutional actors together in a single decision-making platform. In the long-run, NSDE will also have to take up the responsibility of managing and conserving the restored salt marsh (Figure 3).

Fourthly, bureaucratic autonomy in a polycentric institutional system helps build collaborative networks for initiating collective entrepreneurial activities [102]. Figure 2 shows that the jurisdictional distribution of Canadian coasts is multi-level and polycentric [42]. Like most other governance systems across the world, the polycentric coastal jurisdictions are managed by different government agencies for maintaining and deriving multiple services without violating the interests of other institutions $[42,54]$. However, actors in such institutional structures are often dispersed. Building networks among these actors requires agreed upon principles, norms and rules that are developed by a bargaining process [102]. However, the institutional actors require certain levels of autonomy for participating and representing respective agencies in the bargaining process [56,61]. The institutional entrepreneurship theory suggests that resourceful and motivated institutional actors can play effective entrepreneurial roles for institutional change $[29,58]$. This case study shows that the identification of NSDTIR and NSDA's departmental adaptation champions in the NSDE-organized training program was one of the main turning points for the project, as the champions had the required autonomy ('social license within the department' according to one of the respondents of the study) to represent their departmental interest in the negotiation process of distributing roles and responsibilities among the institutional actors for implementing the project.

Fifth, repeated interaction among the institutional actors helped build trust and commitment to work as a unit for obtain a common goal [76]. The NSDE-organized training program gave an opportunity to the institutional actors to communicate and interact among themselves, where they could explain where their respective agencies stand in terms of coastal adaptation. This was the 
place for building networks, what Prell et al. [76] emphasized for stating that institutional network development happens when actors communicate in an informal fashion, suppressing their institutional identity and hierarchal position. We also observed that repeated interaction also helped gain the support and commitment of the Marsh Body members. Taking their queries seriously and answering them with scientific evidence are some gestures that indicated the commitment and carefulness of institutional actors for the interests of the Marsh Body members.

Finally, we conclude that institutional innovation for implementing $\mathrm{NbCA}$ requires the entrepreneurial vision of resourceful actors, who can avoid institutional inertia not by violating the existing institutional structure, being strategic to bridge institutional disconnections and to mobilize required resources (e.g., knowledge, finance, brokering etc.). Although the institutional innovations and entrepreneurial actions performed effectively in the case study project, the general lessons obtained from this study have wider implications to implement NbCA in different parts of the world. To take advantage of these lessons, institutional entrepreneurs need to be reflexive in terms of understanding their own contexts and identifying what actions are to be taken under the broader outline of institutional innovation described in this paper. Moreover, building on the case study outcomes, theoretical assumptions and the nature of climate change impacts, we suggest that coastal adaptation policies need to be flexible to allow institutional actors to innovate, rather than implementing rigid policy recommendations coming from upper levels of the institutional hierarchy. Therefore, to be considered as a viable institutional structure, every institutional innovation should pass through rigorous performance evaluation in terms of its effectiveness to implement $\mathrm{NbCA}-\mathrm{a}$ potential avenue for future research.

Author Contributions: Conceptualization: H.M.T.R., K.S. and D.v.P.; Data curation: K.S. and H.M.T.R.; Formal analysis: H.M.T.R. and K.S.; Funding acquisition: D.v.P. and K.S.; Investigation: H.M.T.R., K.S. and D.v.P.; Methodology: H.M.T.R. and K.S.; Project administration: K.S. and D.v.P.; Resources: K.S. and D.v.P.; Supervision: K.S. and D.v.P.; Validation: D.v.P.; Visualization: H.M.T.R.; Writing一original draft: H.M.T.R.; Writing一review \& editing: K.S. and D.v.P.

Funding: This research was funded by the Organization of Economic Co-operation and Development (OECD) and Natural Resources Canada (NRCan) of the Government of Canada (van Proosdij, PI).

Acknowledgments: We greatly appreciate the willingness of all interviewees and workshop attendees for sharing their experiences and views. We are also in debt to the anonymous reviewers of this paper for their thoughtful comments to improve the original manuscript.

Conflicts of Interest: The authors declare no conflicts of interest.

\section{References}

1. Church, J.A.; Clark, P.U.; Cazenave, A.; Gregory, J.M.; Jevrejeva, S.; Levermann, A.; Merrifield, M.A.; Milne, G.A.; Nerem, R.S.; Nunn, P.D.; et al. Sea Level Change. In Climate Change 2013: The Physical Science Basis Contribution of Working Group I to the Fifth Assessment Report of the Intergovernmental Panel on Climate Change; Stocker, T.F., Qin, D., Plattner, G.-K., Tignor, M., Allen, S.K., Boschung, J., Nauels, A., Xia, Y., Bex, V., Midgley, P.M., Eds.; Cambridge University Press: Cambridge, UK; New York, NY, USA, 2013; pp. 1137-1216.

2. Lemmen, D.S.; Warren, F.J. Synthesis. In Canada's Marine Coasts in a Changing Climate; Lemmen, D.S., Warren, F.J., James, T.S., Clarke, C.S.L.M., Eds.; Government of Canada: Ottawa, ON, Canada, 2016; pp. 17-26.

3. Clarke, C.S.L.M.; Manuel, P.; Warren, F.J. The coastal challenge. In Canada's Marine Coasts in a Changing Climate; Lemmen, D.S., Warren, F.J., James, T.S., Clarke, C.S.L.M., Eds.; Government of Canada: Ottawa, ON, Canada, 2016; pp. 69-98.

4. Abel, N.; Gorddard, R.; Harman, B.; Leitch, A.; Langridge, J.; Ryan, A.; Heyenga, S. Sea level rise, coastal development and planned retreat: Analytical framework, governance principles and an Australian case study. Environ. Sci. Policy 2011, 14, 279-288. [CrossRef]

5. Hinkel, J.; Lincke, D.; Vafeidis, A.T.; Perrette, M.; Nicholls, R.J.; Tol, R.S.; Marzeion, B.; Fettweis, X.; Ionescu, C.; Levermann, A. Coastal flood damage and adaptation costs under 21st century sea-level rise. Proc. Natl. Acad. Sci. USA 2014, 111, 3292-3297. [CrossRef] 
6. Dugan, J.E.; Airoldi, L.; Chapman, M.G.; Walker, S.J.; Schlacher, T. Estuarine and Coastal Structures: Environmental Effects, a Focus on Shore and Nearshore Structures. In Treatise on Estuarine and Coastal Science; Wolanski, E., McLusky, D., Eds.; Academic Press: Waltham, MA, USA, 2011; pp. 17-41. [CrossRef]

7. Kabisch, N.; Frantzeskaki, N.; Pauleit, S.; Naumann, S.; Davis, M.; Artmann, M.; Haase, D.; Knapp, S.; Korn, H.; Stadler, J.; et al. Nature-based solutions to climate change mitigation and adaptation in urban areas: Perspectives on indicators, knowledge gaps, barriers, and opportunities for action. Ecol. Soc. 2016, 21. [CrossRef]

8. Bulleri, F.; Chapman, M.G. The introduction of coastal infrastructure as a driver of change in marine environments. J. Appl. Ecol. 2010, 47, 26-35. [CrossRef]

9. Barnett, J.; O’Neill, S. Maladaptation. Glob. Environ. Chang. 2010, 20, 211-213. [CrossRef]

10. Temmerman, S.; Kirwan, M.L. Building land with a rising sea. Science 2015, 349, 588-589. [CrossRef] [PubMed]

11. Sovacool, B.K. Hard and soft paths for climate change adaptation. Clim. Policy 2011, 11, 1177-1183. [CrossRef]

12. Schoonees, T.; Gijón Mancheño, A.; Scheres, B.; Bouma, T.J.; Silva, R.; Schlurmann, T.; Schüttrumpf, H. Hard Structures for Coastal Protection, Towards Greener Designs. Estuaries Coasts 2019. [CrossRef]

13. Morris, R.L.; Konlechner, T.M.; Ghisalberti, M.; Swearer, S.E. From grey to green: Efficacy of eco-engineering solutions for nature-based coastal defence. Glob. Chang. Biol. 2018, 24, 1827-1842. [CrossRef] [PubMed]

14. Temmerman, S.; Meire, P.; Bouma, T.J.; Herman, P.M.; Ysebaert, T.; De Vriend, H.J. Ecosystem-based coastal defence in the face of global change. Nature 2013, 504, 79-83. [CrossRef]

15. Cheong, S.-M.; Silliman, B.; Wong, P.P.; van Wesenbeeck, B.; Kim, C.-K.; Guannel, G. Coastal adaptation with ecological engineering. Nat. Clim. Chang. 2013, 3, 787-791. [CrossRef]

16. MacDonald, M.A.; de Ruyck, C.; Field, R.H.; Bedford, A.; Bradbury, R.B. Benefits of coastal managed realignment for society: Evidence from ecosystem service assessments in two UK regions. Estuar. Coast. Shelf Sci. 2017. [CrossRef]

17. Jones, H.P.; Hole, D.G.; Zavaleta, E.S. Harnessing nature to help people adapt to climate change. Nat. Clim. Chang. 2012, 2, 504-509. [CrossRef]

18. Juhola, S.; Glaas, E.; Linnér, B.-O.; Neset, T.-S. Redefining maladaptation. Environ. Sci. Policy 2016, 55, 135-140. [CrossRef]

19. OECD. Responding to Rising Seas: OECD Country Approaches to Tackling Coastal Risks; OECD Publishing: Paris, France, 2019.

20. Mitsch, W.J.; Jørgensen, S.E. Ecological engineering: A field whose time has come. Ecol. Eng. 2003, 20, 363-377. [CrossRef]

21. Moudrak, N.; Feltmate, B.; Venema, H.; Osman, H. Combating Canada's Rising Flood Costs: Natural Infrastructure Is an Underutilized Option; Intact Centre on Climate Adaptation, University of Waterloo: Waterloo, ON, Canada, 2018.

22. Matthews, T.; Lo, A.Y.; Byrne, J.A. Reconceptualizing green infrastructure for climate change adaptation: Barriers to adoption and drivers for uptake by spatial planners. Landsc. Urban Plan. 2015, 138, 155-163. [CrossRef]

23. Munang, R.; Thiaw, I.; Alverson, K.; Mumba, M.; Liu, J.; Rivington, M. Climate change and Ecosystem-based Adaptation: A new pragmatic approach to buffering climate change impacts. Curr. Opin. Environ. Sustain. 2013, 5, 67-71. [CrossRef]

24. Narayan, S.; Beck, M.W.; Reguero, B.G.; Losada, I.J.; van Wesenbeeck, B.; Pontee, N.; Sanchirico, J.N.; Ingram, J.C.; Lange, G.M.; Burks-Copes, K.A. The Effectiveness, Costs and Coastal Protection Benefits of Natural and Nature-Based Defences. PLoS ONE 2016, 11, e0154735. [CrossRef]

25. Ferrario, F.; Beck, M.W.; Storlazzi, C.D.; Micheli, F.; Shepard, C.C.; Airoldi, L. The effectiveness of coral reefs for coastal hazard risk reduction and adaptation. Nat. Commun. 2014, 5, 3794. [CrossRef]

26. Spalding, M.D.; McIvor, A.L.; Beck, M.W.; Koch, E.W.; Möller, I.; Reed, D.J.; Rubinoff, P.; Spencer, T.; Tolhurst, T.J.; Wamsley, T.V.; et al. Coastal Ecosystems: A Critical Element of Risk Reduction. Conserv. Lett. 2014, 7, 293-301. [CrossRef]

27. North, D.C. Institutions. J. Econ. Perspect. 1991, 5, 97-112. [CrossRef]

28. March, J.G.; Olsen, J.P. Institutional Perspectives on Political Institutions. Gov. Int. J. Policy Adm. 1996, 9, 247-264. [CrossRef] 
29. Garud, R.; Hardy, C.; Maguire, S. Institutional Entrepreneurship as Embedded Agency: An Introduction to the Special Issue. Organ. Stud. 2016, 28, 957-969. [CrossRef]

30. Ostrom, E. Understanding Institutional Diversity; Princeton Univrsity Press: New Jersey, NJ, USA, 2005.

31. Rahman, H.M.T.; Ville, A.S.S.; Song, A.M.; Po, J.Y.T.; Berthet, E.; Brammer, J.R.; Brunet, N.D.; Jayaprakash, L.G.; Lowitt, K.N.; Rastogi, A.; et al. A framework for analyzing institutional gaps in natural resource governance. Int. J. Commons 2017, 11, 823-853. [CrossRef]

32. Ostrom, E. Governing the Commons; Cambridge University Press: Cambridge, UK, 1990.

33. Suchman, M.C. Managing Legitimacy: Strategic and Institutional Approaches. Acad. Manag. Rev. 1995, 20, 571-610. [CrossRef]

34. Ostrom, E. Design Principles in Long-Enduring Irrigation Institutions. Water Resour. Res. 1993, 29, $1907-1912$.

35. Libecap, G.D. Institutional Path Dependence in Climate Adaptation: Coman's "Some Unsettled Problems of Irrigation". Am. Econ. Rev. 2011, 101, 64-80. [CrossRef]

36. Klein Woolthuis, R.; Hooimeijer, F.; Bossink, B.; Mulder, G.; Brouwer, J. Institutional entrepreneurship in sustainable urban development: Dutch successes as inspiration for transformation. J. Clean. Prod. 2013, 50, 91-100. [CrossRef]

37. Woodhill, J. Capacities for Institutional Innovation: A Complexity Perspective. IDS Bull. 2010, 41, 47-59. [CrossRef]

38. Lawrence, T.B.; Hardy, C.; Phillips, N. Institutional Effects of Interorganizational Collaboration: The Emergence of ProtoInstitutions. Acad. Manag. J. 2002, 45, 281-290.

39. Kisfalvi, V.; Maguire, S. On the Nature of Institutional Entrepreneurs: Insights from the Life of Rachel Carson. J. Manag. Inq. 2011, 20, 152-177. [CrossRef]

40. Rodima-Taylor, D.; Olwig, M.F.; Chhetri, N. Adaptation as innovation, innovation as adaptation: An institutional approach to climate change. Appl. Geogr. 2012, 33, 107-111. [CrossRef]

41. Chhetri, N.; Chaudhary, P.; Tiwari, P.R.; Yadaw, R.B. Institutional and technological innovation: Understanding agricultural adaptation to climate change in Nepal. Appl. Geogr. 2012, 33, 142-150. [CrossRef]

42. Ostrom, V. Polycentricity: The structural basis of self-governing systems. In Choice, Rules and Collective Action: The Ostroms on the Study of Institutions and Governance; Sabetti, F., Aligica, P.D., Eds.; ECPR Press: Colchester, UK, 2014.

43. Rahman, H.M.T.; Hickey, G.M. Assessing Institutional Responses to Climate Change Impacts in the North-Eastern Floodplains of Bangladesh. Environ. Manag. 2019, 63, 596-614. [CrossRef] [PubMed]

44. Koene, B.A.S. Situated human agency, institutional entrepreneurship and institutional change. J. Organ. Chang. 2006, 19, 365-382. [CrossRef]

45. Rahman, H.M.T.; Po, J.Y.T.; Saint Ville, A.; Brunet, N.D.; Clare, S.; Darling, S.; Pigford, A.; Mustafa, K.N.; Hickey, G.M. Legitimacy of different knowledge types in natural resource governance and their functions in inter-institutional gaps. Soc. Nat. Resour. 2019, 32, 1344-1363. [CrossRef]

46. Anguelovski, I.; Carmin, J. Something borrowed, everything new: Innovation and institutionalization in urban climate governance. Curr. Opin. Environ. Sustain. 2011, 3, 169-175. [CrossRef]

47. Harries, T.; Penning-Rowsell, E. Victim pressure, institutional inertia and climate change adaptation: The case of flood risk. Glob. Environ. Chang. 2011, 21, 188-197. [CrossRef]

48. Marshall, G.R.; Alexandra, J. Institutional path dependence and environmental water recovery in Australia's Murray-Darling Basin. Water Altern. 2016, 9, 679-703.

49. Munck af Rosenschöld, J.; Rozema, J.G.; Frye-Levine, L.A. Institutional inertia and climate change: A review of the new institutionalist literature. Wiley Interdiscip. Rev. Clim. Chang. 2014, 5, 639-648. [CrossRef]

50. Armitage, D.R.; Okamoto, D.K.; Silver, J.J.; Francis, T.B.; Levin, P.S.; Punt, A.E.; Davies, I.P.; Cleary, J.S.; Dressel, S.C.; Jones, R.R.; et al. Integrating Governance and Quantitative Evaluation of Resource Management Strategies to Improve Social and Ecological Outcomes. BioScience 2019, 69, 523-532. [CrossRef]

51. Barnett, J.; Evans, L.S.; Gross, C.; Kiem, A.S.; Kingsford, R.T.; Palutikof, J.P.; Pickering, C.M.; Smithers, S.G. From barriers to limits to climate change adaptation: Path dependency and the speed of change. Ecol. Soc. 2015, 20. [CrossRef]

52. Morrison, T.H.; Adger, W.N.; Brown, K.; Lemos, M.C.; Huitema, D.; Phelps, J.; Evans, L.; Cohen, P.; Song, A.M.; Turner, R.; et al. The black box of power in polycentric environmental governance. Glob. Environ. Chang. 2019, 57. [CrossRef] 
53. Greenwood, R.; Suddaby, R. Institutional Entrepreneurship in Mature Fields: The Big Five Accounting Firms. Acad. Manag. J. 2006, 49, 27-48. [CrossRef]

54. Ostrom, V.; Tiebout, C.M.; Warren, R. The Organization of Government in Metropolitan Areas: A Theoretical Inquiry. Am. Political Sci. Rev. 1961, 55, 831-842. [CrossRef]

55. Sherren, K.; Bowron, T.; Graham, J.M.; Rahman, H.M.T.; van Proosdij, D. Coastal infrastructure realignment and salt marsh restoration in Nova Scotia, Canada. In Responding to Rising Seas: OECD Country Approaches to Tackling Coastal Risks; Danielson, L., Ed.; OECD Publishing: Paris, France, 2019; pp. 111-135.

56. Fukuyama, F. What Is Governance? Governance 2013, 26, 347-368. [CrossRef]

57. Weik, E. Institutuonal entrepreneurship and agency. J. Theory Soc. Behav. 2011, 41, 466-481. [CrossRef]

58. Maguire, S.; Hardy, C.; Lawrence, T.B. Institutional entrepreneurship in emerging fields: HIV/AIDS treatment advocacy in Canada. Acad. Manag. J. 2004, 47, 657-679.

59. Garud, R.; Jain, S.; Kumaraswamy, A. Institutional Entrepreneurship in the Sponsorship of Common Technological Standards: The Case of Sun Microsystems and Java. Acad. Manag. J. 2002, 45, 196-214.

60. Abdelnour, S.; Hasselbladh, H.; Kallinikos, J. Agency and Institutions in Organization Studies. Organ. Stud. 2017, 38, 1775-1792. [CrossRef]

61. Dorado, S. Institutional Entrepreneurship, Partaking, and Convening. Organ. Stud. 2016, 26, 385-414. [CrossRef]

62. Phillips, N.; Tracey, P. Opportunity recognition, entrepreneurial capabilities and bricolage: Connecting institutional theory and entrepreneurship in strategic organization. Strateg. Organ. 2016, 5, 313-320. [CrossRef]

63. Emirbayer, M.; Mische, A. What Is Agency? Am. J. Sociol. 1998, 103, 962-1023. [CrossRef]

64. Mintrom, M.; Luetjens, J. Policy entrepreneurs and problem framing: The case of climate change. Environ. Plan. C Politics Space 2017, 35, 1362-1377. [CrossRef]

65. Wejs, A.; Harvold, K.; Larsen, S.V.; Saglie, I.-L. Legitimacy building in weak institutional settings:climate change adaptation at local level in Denmark and Norway. Environ. Politics 2013, 23, 490-508. [CrossRef]

66. Mondou, M.; Hickey, G.M.; Rahman, H.M.T.; Maguire, S.; Pain, G.; Crump, D.; Hecker, M.; Basu, N. How are New Approach Methodologies (NAMs) discussed at SETAC events? The implications of professional scientific discourse on the evolution of environmental regulation. Integr. Environ. Assess. Manag. 2020. Forthcoming.

67. Hardy, C.; Maguire, S. Institutional entrepreneurship. In The SAGE Handbook of Organizational Institutionalism; Greenwood, R., Oliver, C., Suddaby, R., Sahlin-Andersson, K., Eds.; Sage Publications Ltd.: London, UK, 2008; pp. 198-217.

68. Sotarauta, M. Institutional Entrepreneurship, Innovation Systems, and Innovation Policy. In Encyclopedia of Creativity, Invention, Innovation and Entrepreneurship; Carayannis, E.G., Ed.; Springer: New York, NY, USA, 2013; pp. 1074-1081.

69. Vuik, V.; Borsje, B.W.; Willemsen, P.W.J.M.; Jonkman, S.N. Salt marshes for flood risk reduction: Quantifying long-term effectiveness and life-cycle costs. Ocean Coast. Manag. 2019, 171, 96-110. [CrossRef]

70. Turner, R.K.; Burgess, D.; Hadley, D.; Coombes, E.; Jackson, N. A cost-benefit appraisal of coastal managed realignment policy. Glob. Environ. Chang. 2007, 17, 397-407. [CrossRef]

71. Feng, X.; Fu, B.; Lu, N.; Zeng, Y.; Wu, B. How ecological restoration alters ecosystem services: An analysis of carbon sequestration in China's Loess Plateau. Sci. Rep. 2013, 3, 2846. [CrossRef]

72. Ajani, J.I.; Keith, H.; Blakers, M.; Mackey, B.G.; King, H.P. Comprehensive carbon stock and flow accounting: A national framework to support climate change mitigation policy. Ecol. Econ. 2013, 89, 61-72. [CrossRef]

73. Johnsen, K.H.; Wear, D.; Oren, R.; Teskey, R.O.; Sanchez, F.; Will, R.; Butnor, J.; Markewitz, D.; Richter, D.; Rials, T.; et al. Meeting global policy commitments: Carbon sequestration and southern pine forests. J. For. 2001, 99, 14-21.

74. Uittenbroek, C.J.; Janssen-Jansen, L.B.; Runhaar, H.A.C. Stimuli for climate adaptation in cities: Insights from Philadelphia-An early adapter. Int. J. Clim. Chang. Strateg. Manag. 2016, 8, 38-56. [CrossRef]

75. Mutch, A. Reflexivity and the institutional entrepreneur: A historical exploration. Organ. Stud. 2007, 28, 1123-1140. [CrossRef]

76. Prell, C.; Reed, M.; Racin, L.; Hubacek, K. Competing structure, competing views: The role of formal and informal social structures in shaping stakeholder perceptions. Ecol. Soc. 2010, 15, 34. [CrossRef]

77. Li, D.D.; Feng, J.; Jiang, H. Institutional Entrepreneurs. Am. Econ. Rev. 2006, 96, 358-362. [CrossRef] 
78. Sherren, K.; Loik, L.; Debner, J.A. Climate adaptation in 'new world' cultural landscapes: The case of Bay of Fundy agricultural dykelands (Nova Scotia, Canada). Land Use Policy 2016, 51, 267-280. [CrossRef]

79. Grieve, M.; Turnbull, L. Emergency Management in Nova Scotia. In Multilevel Governance and Emergency Management in Canadian Municipalities; Henstra, D., Ed.; McGill-Queen's Press (MQUP): Montreal, QC, Canada; Kingston, ON, Canada, 2013; pp. 62-90.

80. Canada, S. Census Profile (Truro Population Centre and Truro Census Metropolitan Area) 2016 Census; Government of Canada: Ottawa, ON, Canada, 2017.

81. Limited, C. Truro Flood Risk Study; Town of Truro: Truro, UK, 2017.

82. Yzaguirre, A.; Smit, M.; Warren, R. Newspaper archives + text mining = rich sources of historical geo-spatial data. IOP Conf. Ser. Earth Environ. Sci. 2016, 34, 012043. [CrossRef]

83. O'Sullivan, T.L.; Kuziemsky, C.E.; Toal-Sullivan, D.; Corneil, W. Unraveling the complexities of disaster management: A framework for critical social infrastructure to promote population health and resilience. Soc. Sci. Med. 2013, 93, 238-246. [CrossRef]

84. Holling, C.S.; Meffe, G.K. Command and Control and the Pathology of Natural Resource Management. Conserv. Biol. 1996, 10, 328-337. [CrossRef]

85. NSDMA. Financial Condition Index. Available online: https://novascotia.ca/dma/finance/indicator/fci.asp (accessed on 10 August 2018).

86. El-Sharif, A.; Hansen, D. Application of SWMM to the Flooding Problem in Truro, Nova Scotia. Can. Water Resour. J. 2001, 26, 439-459. [CrossRef]

87. Mason, J. Qualitative Researching, 2nd ed.; SAGE Publications Ltd.: London, UK, 2002; p. 234.

88. Kallio, H.; Pietila, A.M.; Johnson, M.; Kangasniemi, M. Systematic methodological review: Developing a framework for a qualitative semi-structured interview guide. J. Adv. Nurs. 2016, 72, 2954-2965. [CrossRef] [PubMed]

89. Longhurst, R. Semi-structured interviews and focus groups. In Key Methods in Geography, 2nd ed.; Clifford, N., French, S., Valentine, G., Eds.; SAGE Publications Ltd.: London, UK, 2010; pp. 103-115.

90. Elo, S.; Kyngas, H. The qualitative content analysis process. J. Adv. Nurs. 2008, 62, 107-115. [CrossRef] [PubMed]

91. Flick, U. Triangulation in qualitative research. In A Companion to Qualitative Research; Flick, U., von Kardorff, E., Steinke, I., Eds.; SAGE Publications Inc.: London, UK, 2004; pp. 178-183.

92. Momsen, J.H. Women, men and fieldwork: Gender relations and power structures. In Doing Development Research; Desai, V., Potter, R.B., Eds.; SAGE Publications Ltd.: London, UK, 2006; pp. 44-51.

93. Government of Nova Scotia. Background of Dykelands. Available online: https://novascotia.ca/agri/ documents/Background-of-Dykelands.pdf (accessed on 5 August 2018).

94. Nova Scotia Department of Environment. Adapting to a Changing Climate in Nova Scotia: Vulnerability Assessment and Adaptation Options. Available online: https://climatechange.novascotia.ca/sites/default/ files/uploads/Adapting_to_a_Changing_Climate_in_NS.pdf (accessed on 10 August 2018).

95. van Proosdij, D.; Perrott, B.; Carrol, K. Development and application of a geo-temporal atlas for climate change adaptation in Bay of Fundy dykelands. J. Coast. Res. 2013, 1, 1069-1074. [CrossRef]

96. CBCL Limited. The 2009 State of Nova Scotia's Coast-Technical Report; Province of Nova Scotia: Halifax, NS, Canada, 2009.

97. Harman, B.P.; Heyenga, S.; Taylor, B.M.; Fletcher, C.S. Global lessons for adapting coastal communities to protect against storm surge inundation. J. Coast. Res. 2013, 31, 790-801. [CrossRef]

98. Bowron, T.M.; Neatt, N.; van Proosdij, D.; Lundholm, J. Salt marsh tidal restoration in Canada's maritime provinces. In Tidal Marsh Restoration: The Science and Practice of Ecological Restoration; Roman, C.T., Burdick, D.M., Eds.; Island Press: Washington, DC, USA, 2012; pp. 191-209.

99. Marvin, J.; Wilson, A.T. One dimensional, two dimensional and three dimensional hydrodynamic modeling of a dyked coastal river in the Bay of Fundy. J. Water Manag. Model. 2016, 25, 404. [CrossRef]

100. Mills, M.; Leon, J.X.; Saunders, M.I.; Bell, J.; Liu, Y.; O’Mara, J.; Lovelock, C.E.; Mumby, P.J.; Phinn, S.; Possingham, H.P.; et al. Reconciling Development and Conservation under Coastal Squeeze from Rising Sea Level. Conserv. Lett. 2016, 9, 361-368. [CrossRef] 
101. Pontee, N. Defining coastal squeeze: A discussion. Ocean Coast. Manag. 2013, 84, 204-207. [CrossRef]

102. Wijen, F.; Ansari, S. Overcoming Inaction through Collective Institutional Entrepreneurship: Insights from Regime Theory. Organ. Stud. 2016, 28, 1079-1100. [CrossRef] 